\title{
Students' Ability in Writing Report Text of Grade XI at SMK Negeri 1 Painan
}

\author{
Rahmi Azizah ${ }^{1}$ \\ ${ }^{1}$ English Department, Faculty of Languages and Arts State University of Padang \\ e-mail: rahmiazz82@gmail.com
}

\begin{abstract}
Abstrak. Penelitian ini bertujuan untuk mengetahui kemampuan siswa dalam menulis teks laporan. fokus penelitian ini adalah pada kemampuan siswa dalam menulis Generic Structure dan Language Feature dari teks laporan. partisipan dari penelitian ini adalah siswa kelas XI SMK Negeri 1 Painan. Dalam mengambil sampel, peneliatian ini mengunakan stratified random sampling. Data pada penelitian ini adalah berasal dari teks yang di tulis oleh siswa. kemudian, dalam mengumpulkan data tersebut menggunakan tes menulis. Tes tersebut kemudian di nilai dengan mengunakan rubrik penilaian. Berdasarkan data analisis ditemukan bahwa tidak ada siswa yang memiliki kemampuan Luar Biasa dan Sangat Bagus dalam menulis Teks Laporan, 5 siswa memiliki kemampuan Bagus, 14 siswa memiliki kemampuan Cukup, kemudian 7 siswa memiliki kemampuan Buruk dan 4 siswa memiliki kemampuan Sangat Buruk. Berdasarkan analisis data menunjukan bahwa kemampuan siswa dalam menulis teks laporan adalah Cukup. kemudian, hampir semua siswa tidak lulus nilai batas minimum yaitu 7. oleh karena itu penggunaan pendekatan dan teknik mengajar yang tepat harus dilakukan.
\end{abstract}

Kata kunci: kemampuan siswa; menulis; generic structure; language feature

\section{INTRODUCTION}

Based on Educational Ministry Decree no 24/2014 about the standard of content (Standar ISI) and graduate competency (Standar Kompetensi Lulusan) of 2013 curriculum, the purpose of teaching writing at Vocational High School is to enable students to compose some types of written text. Continuing the aims of curriculum 2006, the types of text are developed in English curriculum includes transactional text, short functional text, and long functional text of certain genres and their application in daily context (Diknas: 2008). It can be said that 2013 curriculum requires teachers to help the students master in producing some genre text.

According to 2013 curriculum, one of the texts that are learned by Vocational school students is report text. Report text is a text that has purpose to describe the way things are, with reference to a range of natural, man-made and social phenomena in our environment Derewiaka (1990: 51). Says that information reports classify and describe the phenomena of ourworld. We use them when we talk about a whole class of things, like bikes. The major focus of this text is on "thing" (or more accurately, a class of thing) rather than a sequence. The topic of the report is usually introduction by an opening general statement or general classification and followed by a series of description paragraphs about the topic.

Based on researcher's formal interview with two of English teacher of SMKN 1 Painan, the students' writing skill indicated generally weak. One indication is the low quality of students' writing in terms of developing and organizing ideas. This condition is also analyzed by Richards and Renandya (2002) who state that the standard of students' writing result could be seen from the way they develop their ideas. It could be seen that writing is difficult skill for second learners to be mastered, the difficulties not only in generating and organizing ideas but also in translating these ideas into readable text.

Several researches have been conducted related to the students' ability in writing text, the research is written by Efrianti (2015) who conducted a study about students' ability in writing generic structure of descriptive text at tenth grade of senior high school 4 padang, the aim of this study is to find out the students' ability in writing generic stracture of descriptive text at tenth grade of senior high school 4 padang. The result found that some of the students of Senior High School 4 Padang at tenth grade were not able to write generic structure of descriptive text well, they did not fulfill some criteria based on Winch's theory such as did not put identification in the first paragraph, described more than one participant, and they also did not describe the thing that they wanted to describe into detail information

The second research by Siahaan (2013) who conducted a study about an analysis of students' ability and difficulties in writing descriptive texts, found revealed that the low achievers were still confused in identifying the schematic structure of descriptive text. Moreover, the low achievers still needed a lot of improvement as they still made a lot of mistakes in the text they wrote.

Related in writing report text Some research have been conducted early. first, Pestaria (2014), in a paper present in IOSR-JHSS entitled 'Students' Difficulties in Writing Report Text at Grade IX of SMP Negeri 5 Tanjung Balai", states that the students in the IX-1 class still had the problems in using grammar features. However, they were able to write generic structure. But they had difficulty in determining the tense and the attribute of a topic in report text. In short, the students of the IX-1 class did not know how From to write the report text well. The second research by Leviana (2013) who conducted a study about Students' difficulties in Writing Report Text of Eleventh Science class of SMAN $1 \mathrm{Kec}$. Harau in 2012/2013 academies year, found that the students of senior high school got difficulty in writing identification and writing description of a report text. She states that, the students are difficult to make general statement which consists of general information about subject report and to describe the subject report specifically and accurately.

Although there are a lot of researchers who have conducted the research previously, this research is different because the researcher investigated the 
students' ability in writing a report text viewed from generic structure and language features at eleven grade SMKN 1 Painan. By analyzing students' ability in writing report text will help to find out students' problems in writing report text.

\section{RESEARCH METHOD}

This research was a descriptive qualitative research because the research was designed to analyze the students' ability in writing a report text text.. Gay (2000:16) state that qualitative research seeks to probe deeply into the research setting in order to obtain understandings about the way things are, why they are that way, and how the participants in the context perceive them.. This research was held in Smk Negeri 1 Painan, at eleven grade students. It was located on at $\mathrm{Jl}$. Moh. HattaPainan, Pesisir Selatan district.

The population of this research was the eleven grade student of SMK negeri 1 Painan in the academic 2017/2018. It consisted of twelve classes. The total population from twelve classes at grade XI of SMKN No. 1 Painan is 323 students. Since the limitatation of ability and time in conducting this research, 32 students was choosed as the sample in this research. In choosing the sample for this research, the researcher takes $10 \%$ from the population. So that, from each class takes three or two students as the sample. As states by Gay (2002) the minimal sample for descriptive study is $10 \%$ of the population while for a relatively small population at least $20 \%$ of the population. And to choose the students to be sample, the writer used proportionate random sampling technique; the researcher writes each name of the students in each class. After that, the researcher rolledup paper that written of the students' name. Then, it is taken randomly based on the number of sample of each class.

The research instrument for this research was writing test. The Instrument was used to find out the result of the students' writing ability. In analyzing the data, the writer used rubrics of writing adapted from by Brown (2004:244) and Raison (1994:39).. The test is constructed based on some indicators of report text they are identification that consist of general classification paragraph and description paragraph and then, languaguage features of report text that consist of timeless present tense, Technical terms, relating verbs and common noun.

In collecting the data for this research, the researcher distributed the sheet of written test of report text text. There were some procedures that had been done. First, the researcher asked the student in class XI to write a report text based on four topics that researcher offer. Then, the students choose one topic from four topics offered to develop into a report text and the writer explained to the students about what they should do during the test. The test was observed by the researcher. The time of the test is 90 minutes. The last, the researcher collected the students paper to be scored. After collecting the data, the researcher analyzed the result of the research. The researcher analyzed the data in several steps: first, the students writing were scored by the three scorers about generic structure; identification and description, language features; timeless present tense, technical terms, relating verbs and common noun. Second, after all of the students' text were scored, Then, the researcher analyzed the students' writing based on the criterion of writing score that they get in their writing. And to get the conclusion of the students' ability in writing report text the researcher got it from the students' mean score in writing report text and then interpret the scores into arikunto's criterion; they are excellent, good, average, poor or very poor. The table criterion of writing score purposed by Arikunto $(2013: 245)$. It could be seen in the following table below.

Table 1. The interpretation range of students' writing achievement

\begin{tabular}{cc}
\hline Test score & Probable class performance \\
\hline $91-100$ & Excellent \\
$81-90$ & Very good \\
$71-80$ & good \\
$61-70$ & Fair \\
$51-60$ & Poor \\
Less than 50 & Very Poor
\end{tabular}

\section{FINDING AND DISCUSSION}

This research was done at the second year students of SMKN 1 Painan in academic year 2017/20018. There were 32 students takes as the sample of this research. The data of this research are students' writing of report text. The writing ability was scored by two scorers; both of them were teachers at SMKN 1 Painan and the researcher itself. And it was scored based on the scoring rubric of report text was developed from Brown (2004:244) and Raison (2004:38).The scorers were using the same scoring rubric to analyze the students' writing ability of report text. The data were analyzed based on the generic structure of report which consist of identification paragraph and description paragraphs and language features of report text, they are timeless present tense, Technical term, relating words and common noun.

The scores from both scorers were calculated different scale based on the scoring rubric of writing report text. Furthermore, since the score of the students' ability in writing report text is taken from two scorers, the consistency of the both scorers should be calculated. To see the consistency of the score, it is needed to see the reliability of the score by calculating the data by using product moment formula.

Based on the calculation of the product moment formula above the consistency of the score was 0.92 from the reliability of both scores, it can be categorized that the consistency of score is very high reliability. It means that the score could be accepted as the data of the research.

After administering the writing test to the students and calculating the result of writing score, found that the Percentage of students ability in writing report text is as bellow: 
Table 2. Percentage of students' ability in writing report text

\begin{tabular}{cccc} 
Score & Category & $\begin{array}{c}\text { Number of } \\
\text { students }\end{array}$ & $\begin{array}{c}\text { Percentag } \\
\text { e }\end{array}$ \\
$91-100$ & Excellent & 0 & $0 \%$ \\
$81-90$ & Very good & 0 & $0 \%$ \\
$71-80$ & good & 5 & $15.625 \%$ \\
$61-70$ & fair & 14 & $43.75 \%$ \\
$51-60$ & poor & 11 & $34.37 \%$ \\
Less than 50 & Very poor & 2 & $6.25 \%$ \\
Total & & 32 & $100 \%$ \\
\hline
\end{tabular}

The table 2. shows that there were five (15.625\%) students had good ability in writing report text, there were four teen (43.75\%) students had fair ability, eleven students $(34.37 \%)$ had poor ability and two $(6,25 \%)$ students had very poor ability in writing report text. It can be said that the second year students' ability in writing report text of SMKN 1 Painan was fair because most of students had fair ability in writing report text. It means that the students had problems in writing report text.

Also, the students' ability of writing report text can be see from the students'score in of writing components report text. it can be see in the table below:

Table 3. The students' score and category in writing
report text (Generic Structure and Language Features)

Rubric Score1 Scorer 2 Total $\begin{aligned} & \text { Categ } \\ & \text { ory }\end{aligned}$

\begin{tabular}{lcccc}
$\begin{array}{l}\text { General } \\
\text { classification }\end{array}$ & 16,125 & 17,94 & 17,03 & Fair \\
Description & $\begin{array}{c}17,16 \\
\text { Language }\end{array}$ & $\begin{array}{c}18,7 \\
\text { Feature }\end{array}$ & 17,92 & Fair \\
$\begin{array}{l}\text { Timeless } \\
\text { present tense }\end{array}$ & 6,19 & 7 & 6,41 & Fair \\
$\begin{array}{l}\text { Technical terms } \\
\text { Relating verb }\end{array}$ & 6,7 & 6,09 & 6,89 & Good \\
Common noun & 6,53 & 7,75 & 7,6 & Good \\
\hline
\end{tabular}

The table 3. above shows that the students' ability of writing report text of general classification is categorized into fair in score 17.03 in category fair. For the description, the students' ability is in score 17.92 in category fair and language features of report text of timeless present tense is categorized fair in score 6,41 and the technical terms in score 6.89 in category good, the relating verb in score 7,6 in category good and the common noun in score 6,6 in category good.

In summary, from the result finding, the students' ability in writing report text was fair. Also, most of students cannot achieve the passing grade which was 7 . It means that, this research with the title 'Students; Ability in report Text at Eleventh Grade Students of SMKN 1 Painan" was found that the students still have problem in developing the general classification and description paragraph, using language features of report text of timeless present tense and, to achieve the passing grade, and report text was hard to the students at the eleventh grade of vocational school.

\section{CONCLUSION}

Based on the findings it can be concluded that the students' ability in writing report at the second grade SMKN Painan was fair. It was based on the analysis of all of indicators in this research. Concerning with generic structure (general classification and description paragraph) and language features of report texts that consist of timeless present tense, technical terms, relating verbs and common noun. where the average students' score was 62.6 and it cannot achieve the passing grade.

\section{REFERENCES}

Arikunto, S. (2013). Prosedur Penelitian: Suatu Pendekatan Praktek. Jakarta: PT. Rineka Cipta.

Brown, H. Douglas. (2004). Language assessment: Principles and classroom practices. White Plains, NY: Pearson Education

Depdiknas. (2013) Kurikulum bahasa Inggris SMK. Jakarta:Depdiknas

Derewianka, B. (1990). Exploring How Text Work. Australia: Sydney

Efrianti, Rini.(2015). An Analysis of Students' Ability in Writing Generic Structure of Descriptive Text (a study at tenth grade of senior high school 4 padang 2014/2015 academic year) jim.stkip-pgrisumbar.ac.id/jurnal/download/6118

Gay, L. R. (2000). Educational research competencies for analysis and application. Lahore: Combine Printers (Pvt) Ltd.

Kellogg, R. T., Olive, T., \& Pilot, A. (2001). Verbal, visual and spatial working

memory in written language production. ACTA Psychologica. 124, 382-397.

Leviana, Sari. (2013). Students' difficulties in writing report text of eleventh science class of SMAN 1 Kec. Harau in 2012/2013 academies year jim.stkip-pgri-sumbar.ac.id/jurnal/download/5931

Nickerson, R. S., Perkins, D. N., \& Smith, E. E. (1985). The teaching of thinking. Hillsdale, NJ: Erlbaum

Pestaria,Friska.(2014) .Students' difficulties in writing report text at garde IX of SMP negeri 5 Tanjung Balai. IOSR Journal of Humanities and Social Science

Richards, J. C. \& Renandya, W. A. (2002). Methodology in Language Teaching: an anthology of current practice. New York: Cambridge

Raison, Glenda. 1994. Writing resource book. English. Published Melbourne: Longman Australia

Siahaan, Junita.( 2013). An Analysis of Students' Ability and Difficulties in Writing Descriptive texts.ejournal.upi.edu/index.php/L-

E/article/view/355 